\title{
Antigens and Enzymes of Bacteroides of the Bacteroides fragilis Group Compared by Crossed Immunoelectrophoresis
}

\author{
VÉRONIQUE ROGEMOND AND ROLAND M. F. GUINET* \\ Institut Pasteur de Lyon et du Sud-Est, Centre d'Immunochimie Microbienne, 69365 Lyon Cedex 7, France
}

\begin{abstract}
In this work we were primarily concerned with antigens of Bacteroides strains belonging to the $B$. fragilis group. The following two antisera were produced: anti-Bacteroides fragilis $\mathrm{E1}^{\mathrm{T}}(\mathrm{T}=$ type strain) and anti-Bacteroides distasonis. Reference patterns for both of these species were established by crossed immunoelectrophoresis, and these patterns yielded 62 and 70 precipitates, respectively. The crossed reactions of $B$. fragilis $\mathbf{E 1}^{\mathrm{T}}$ and $B$. distasonis with Bacteroides fragilis $\mathrm{E} 2$, Bacteroides thetaiotaomicron, Bacteroides ovatus, and Bacteroides vulgatus were studied to test both for total antigens and for certain enzymes (esterase, phosphatase, malate dehydrogenase, and glucose-6-phosphate dehydrogenase). Our results showed that $B$. thetaiotaomicron is the species which is closest to $B$. fragilis, demonstrating more than $70 \%$ common antigens, whereas none of the species examined was very closely related to $B$. distasonis. Species-specific antigens, such as the phosphatase of $B$. fragilis, as well as antigens common to the group, such as malate dehydrogenase, were also demonstrated in crossed immunoelectrophoresis. This may allow immunological identification of each species.
\end{abstract}

Anaerobic bacteria are responsible for at least $10 \%$ of all bacterial infections, and Bacteroides species alone represent $27 \%$ of the anaerobes isolated from pathological materials (22). Bacteroides strains belonging to the $B$. fragilis group are most often responsible for intestinal infections $(6,27)$. The most frequently isolated species is Bacteroides fragilis, although this species is a minor component of the fecal flora, in which Bacteroides vulgatus and Bacteroides thetaiotaomicron are the dominant species (18). This observation has led some authors to seek virulence factors in $B$. fragilis (notably in the capsule) that are lacking in the other species of the group $(13,19)$.

Classification of the $B$. fragilis group has been modified often. The numerous phenotypic properties which members of this group have in common account for the proposal of subspecies of $\boldsymbol{B}$. fragilis (17). However, deoxyribonucleic acid-deoxyribonucleic acid homology studies showed a diversity (3) which led to reclassification of $B$. fragilis, Bacteroides ovatus, B. vulgatus, B. thetaiotaomicron, and Bacteroides distasonis as distinct species (12).

In 1971, Beerens et al. (1) proposed a serological classification for the $B$. fragilis group, which was based on agglutination or gel double-diffusion tests in the presence of a specific antiserum. Lambe and Moroz (15) tested for the presence of thermostable antigens that permitted classification of all $B$. fragilis strains without cross-reactions with $B$. distasonis, B. ovatus, and B. thetaiotaomicron. Other authors have studied the lipopolysaccharide fractions or outer membrane complex of $\boldsymbol{B}$. fragilis by using either sodium dodecyl sulfate-polyacrylamide gel electrophoresis $(4,14$, 21 ) or immunochemical techniques $(5,10)$.

All of these studies demonstrated the heterogeneity which exists within the $B$. fragilis group, as well as the heterogeneity among the $B$. fragilis strains.

Shah and Collins (23) have shown that the presence of the enzyme glucose-6-phosphate dehydrogenase (G6PDH) is specific for the $B$. fragilis group. The electrophoretic mobilities of certain enzymes were found to be species specific (24).

\footnotetext{
* Corresponding author.
}

This study had the following purposes: to obtain crossed immunoelectrophoretic patterns for soluble antigens of two species of the $B$. fragilis group with the corresponding polyvalent antisera; to compare reactions of other species belonging to the group with these antisera and to estimate their immunological proximity; and to identify certain antigens with enzymes, to study the cross-reactions of these antigens with other species, and to seek antigens specific for the group or species.

\section{MATERIALS AND METHODS}

Antigens. The antigens were prepared from six strains which represented five species belonging to the $B$. fragilis group; these strains were supplied by $\mathrm{C}$. Romond (Table 1 ). The bacteria, which were grown in anaerobic jars for $72 \mathrm{~h}$ at $37^{\circ} \mathrm{C}$ in Wilkins-West medium (26), were collected by centrifugation for $15 \mathrm{~min}$ at $10,000 \times g$ and then washed three times in physiological saline.

The antigens were extracted by shaking in a Braun ho-

TABLE 1. Cross-reactions between Bacteroides antigens as determined by crossed immunoelectrophoresis

\begin{tabular}{|c|c|c|c|c|c|}
\hline \multirow[b]{2}{*}{ Antigen } & \multirow{2}{*}{$\begin{array}{l}\text { Protein } \\
\text { concn } \\
(\mathrm{g} / \text { liter })\end{array}$} & \multicolumn{2}{|c|}{$\begin{array}{l}\text { B. fragilis } \mathrm{E} 1^{\mathrm{T}} \\
\text { antiserum }\end{array}$} & \multicolumn{2}{|c|}{$\begin{array}{l}\text { B. distasonis } \\
\text { antiserum }\end{array}$} \\
\hline & & $\begin{array}{l}\text { No. of } \\
\text { peaks }\end{array}$ & $\begin{array}{c}\% \text { Of } \\
\text { common } \\
\text { antigens }\end{array}$ & $\begin{array}{l}\text { No. of } \\
\text { peaks }\end{array}$ & $\begin{array}{c}\% \text { Of } \\
\text { common } \\
\text { antigens }\end{array}$ \\
\hline $\begin{array}{l}\text { B. fragilis } \mathrm{E} 1^{\mathrm{T}} \\
\left(=\text { NCTC } 9343^{\mathrm{T}}\right)\end{array}$ & 10 & 62 & & 9 & 12.5 \\
\hline $\begin{array}{l}\text { B. fragilis E2 } \\
\text { (E323) }\end{array}$ & 10 & 54 & 87 & 10 & 14 \\
\hline $\begin{array}{l}\text { B. thetaiotaomicron } \\
\text { NCTC } 10582^{\mathrm{T}}\end{array}$ & 10 & 44 & 71 & 12 & 17 \\
\hline $\begin{array}{l}\text { B. ovatus } \\
\text { ATCC } 8483^{\mathrm{T}}\end{array}$ & 2 & 25 & 40 & 35 & 49 \\
\hline $\begin{array}{l}\text { B. vulgatus } \\
\text { ATCC } 8482^{\mathrm{T}}\end{array}$ & 8 & 17 & 27 & 22 & 31 \\
\hline $\begin{array}{l}\text { B. distasonis } \\
\text { ATCC } 8503^{\mathrm{T}}\end{array}$ & 10 & 21 & 34 & 70 & \\
\hline
\end{tabular}


TABLE 2. Enzymes detected by crossed immunoelectrophoresis

\begin{tabular}{|c|c|c|c|c|c|c|c|c|}
\hline \multirow{2}{*}{ Antigen } & \multicolumn{4}{|c|}{ B. fragilis antiserum } & \multicolumn{4}{|c|}{ B. distasonis antiserum } \\
\hline & Esterase & Phosphatase & $\mathrm{MDH}$ & G6PDH & Esterase & Phosphatase & $\mathrm{MDH}$ & G6PDH \\
\hline B. fragilis $\mathrm{E} 1^{\mathrm{T}}$ & + & + & + & + & - & - & + & - \\
\hline B. thetaiotaomicron & - & - & + & + & - & - & + & - \\
\hline B. ovatus & - & - & + & + & - & + & + & - \\
\hline B. vulgatus & - & - & + & - & - & + & + & - \\
\hline B. distasonis & - & - & + & - & + & + & + & - \\
\hline
\end{tabular}

mogenizer; the bacteria were suspended in saline and were placed into a 70-ml flask (Braun Melsungen) containing $50 \mathrm{~g}$ of fine beads (diameter, 0.17 to $0.18 \mathrm{~mm}$ ) and humidified with $10 \mathrm{ml}$ of saline. The antigens were extracted by homogenization for $2 \mathrm{~min}$ at $2,800 \mathrm{rpm}$, using $\mathrm{CO}_{2}$ as the cooling agent. The mixture was filtered to discard the beads and then centrifuged for $1 \mathrm{~h}$ at $20,000 \times g$. The supernatant was
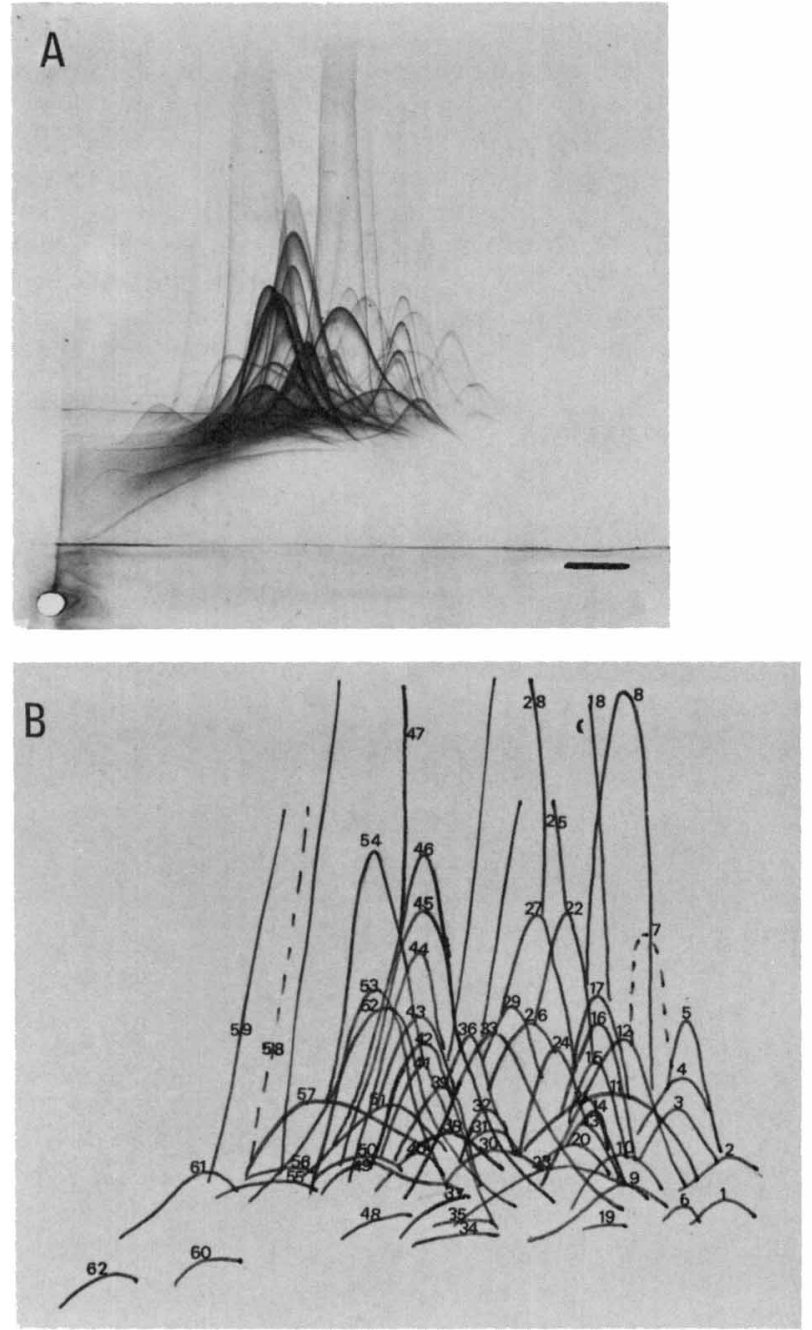

FIG. 1. Crossed-immunoelectrophoresis pattern of $B$. fragilis NCTC $9343^{\mathrm{T}}$. (A) Coomassie brilliant blue-stained plate. The antigen used was $10 \mu \mathrm{l}$ of $B$. fragilis extract in the cathodic well, and the antibody was $10 \mu$ l of the corresponding rabbit antiserum per $\mathrm{cm}^{2}$. (B) Drawing of the 62 precipitates. lyophilized, and the protein concentration was determined by the method of Lowry et al. (16).

The presence of enzymes in the antigenic extracts was tested for either by zone electrophoresis in agarose, using the enzymic staining technique, or by the API-ZYM strip system (API Système, Montalieu Vercieu, France).

Antisera. Antisera were obtained by immunizing rabbits
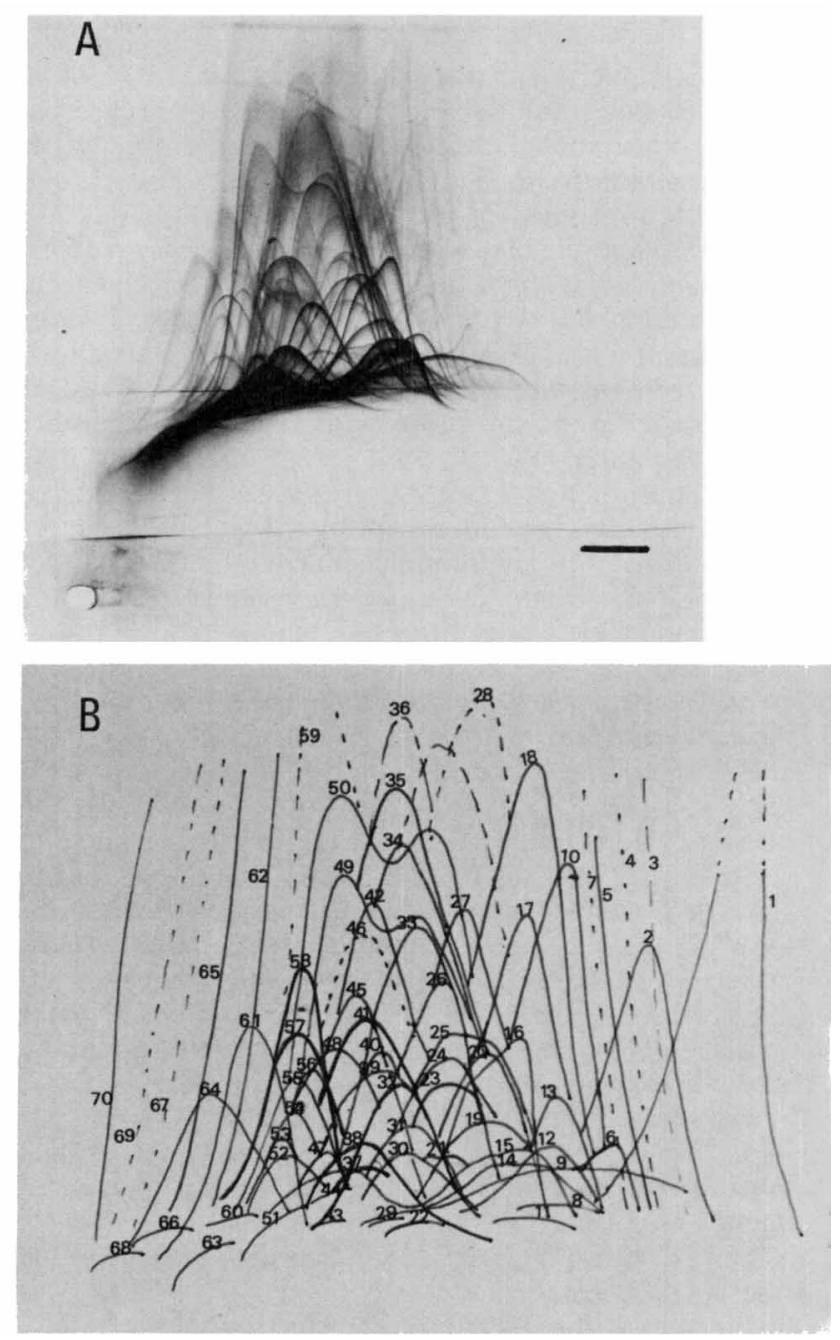

FIG. 2. Crossed-immunoelectrophoresis pattern of $B$. distasonis ATCC $8503^{\mathrm{T}}$ (A) Coomassie brilliant blue-stained plate. The antigen used was $10 \mu \mathrm{l}$ of $B$. distasonis extract in the cathodic well, and the antibody was $15 \mu$ l of the corresponding rabbit antiserum per $\mathrm{cm}^{2}$. (B) Drawing of the 70 precipitates. 

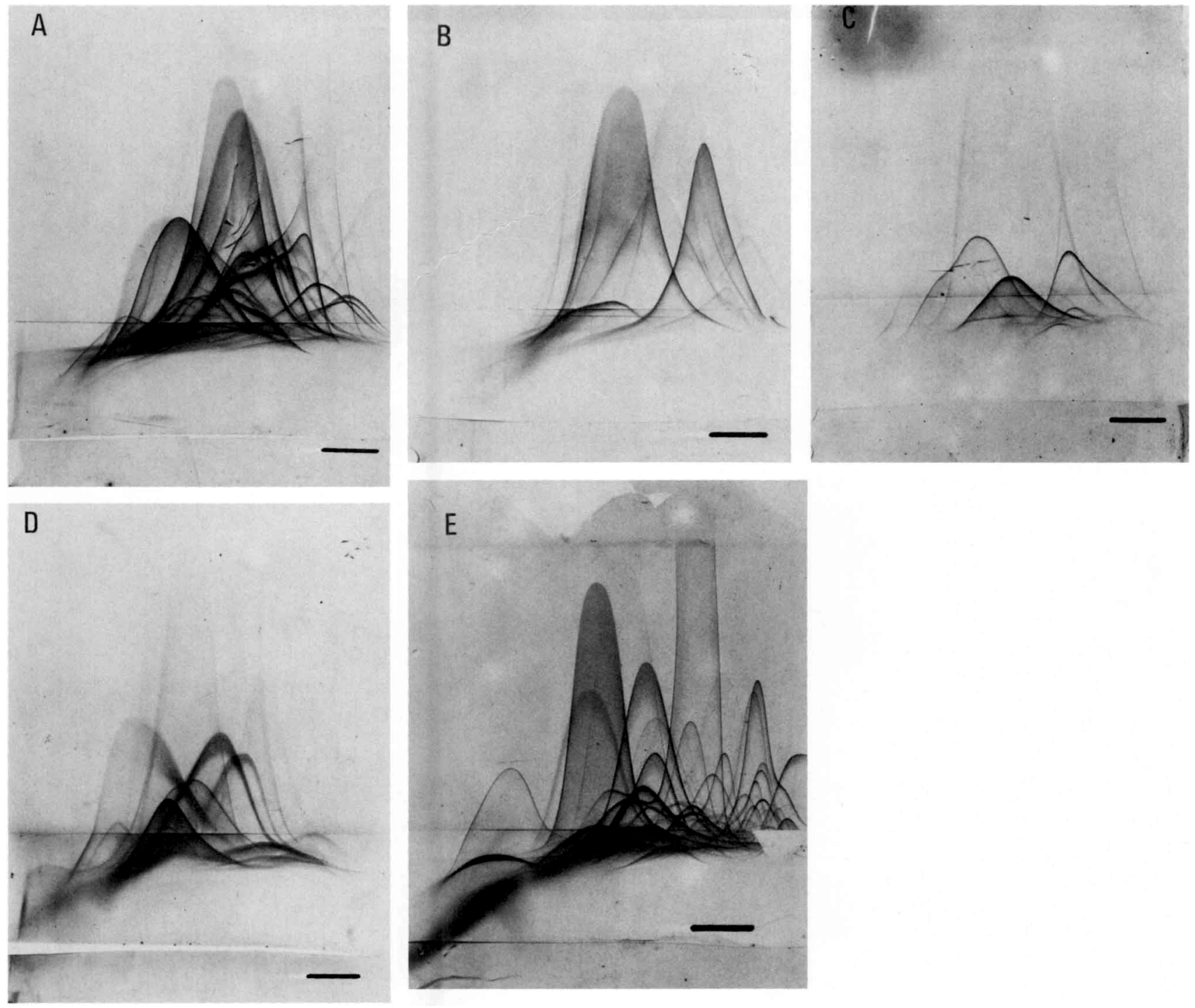

FIG. 3. Crossed immunoelectrophoresis in the heterologous system. The antibody used was $10 \mu$ of rabbit antiserum against $B$. fragilis NCTC $9343^{\mathrm{T}}$ extract per $\mathrm{cm}^{2}$. The antigens used were $10 \mu \mathrm{l}$ of $B$. thetaiotaomicron soluble extract (A), $10 \mu l$ of $B$. ovatus soluble extract (B), $10 \mu \mathrm{l}$ of $B$. vulgatus soluble extract (C), $10 \mu \mathrm{l}$ of $B$. distasonis soluble extract (D), and $10 \mu \mathrm{l}$ of $B$. fragilis E323 soluble extract (E)

with soluble extracts of $B$. fragilis $\mathrm{E} 1$ ( $\mathrm{T}=$ type strain) and B. distasonis.

Immunizations, as well as evaluations of the titers of serum antibodies, were performed by previously described methods (7).

Crossed immunoelectrophoresis. Crossed immunoelectrophoresis was performed in $1 \%$ (wt/vol) agarose medium that was dissolved in $0.025 \mathrm{M}$ tris(hydroxymethyl)aminomethane-barbital buffer ( $\mathrm{pH}$ 8.6) by using the method of Weeke (25), as described previously (7). Briefly, $10 \mu \mathrm{l}$ of antigenic mixture was used for first-dimension electrophoresis, and the antigens thus separated migrated into a gel containing 10 to $15 \%$ antibodies during the second-dimension electrophoresis.

Staining of plates. The plates were either stained with Coomassie blue, as previously described (7), or subjected to enzyme staining. In the latter case, the gels were pressed but not dried.
Esterases and phosphatases. The gels were incubated at room temperature in phosphate-buffered saline $(\mathrm{pH} 7.4)$ containing the substrate dissolved in the appropriate solvent and a diazonium salt (Fast Red TR) (2).

The substrates used were $\alpha$-naphthol acetate dissolved in acetone (for esterases) and naphthol phosphate dissolved in distilled water (for phosphatases).

Dehydrogenases. The dehydrogenase (20) test mixtures were incubated at room temperature in tris(hydroxymethyl)aminomethane hydrochloride buffer ( $\mathrm{pH} 7.5)$.

For malate dehydrogenase (MDH) the test mixture contained (per $100 \mathrm{ml}$ of buffer) $40 \mathrm{mg}$ of potassium cyanide, $2.16 \mathrm{~g}$ of sodium malate dissolved in $12 \mathrm{ml}$ of distilled water, $60 \mathrm{mg}$ of nicotinamide adenine dinucleotide, $36 \mathrm{mg}$ of tetranitro blue tetrazolium, and $3 \mathrm{mg}$ of phenazine methosulfate.

For G6PDH the test mixture contained (per $100 \mathrm{ml}$ of buffer) $400 \mathrm{mg}$ of magnesium chloride, $37 \mathrm{mg}$ of nicotinamide 

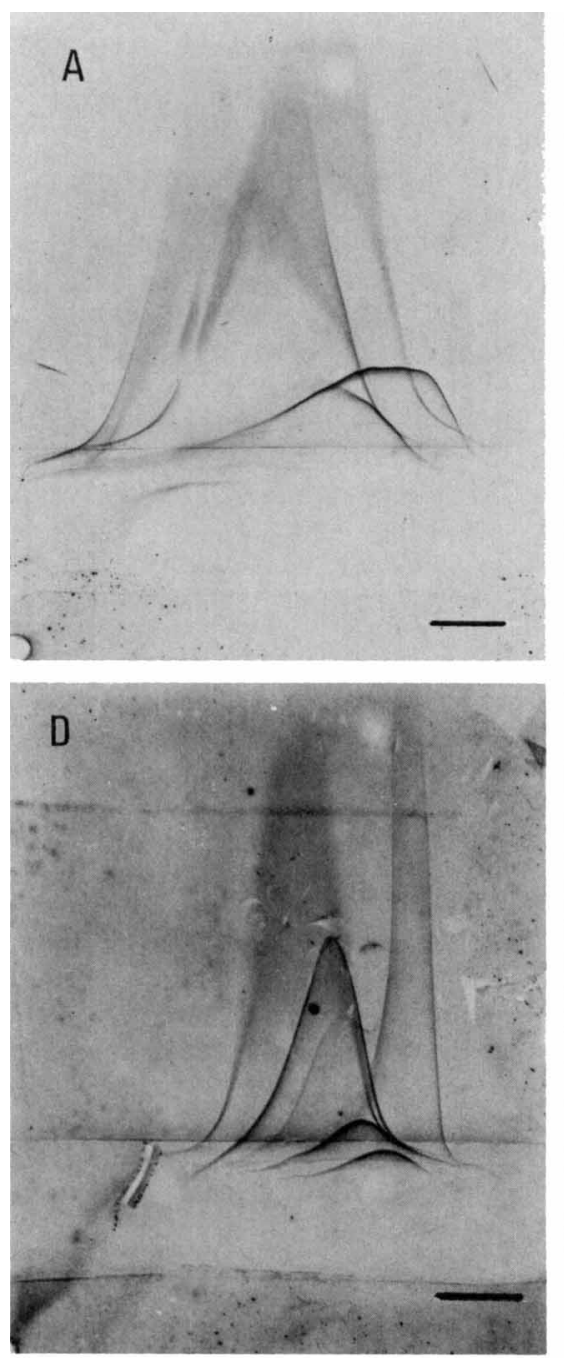
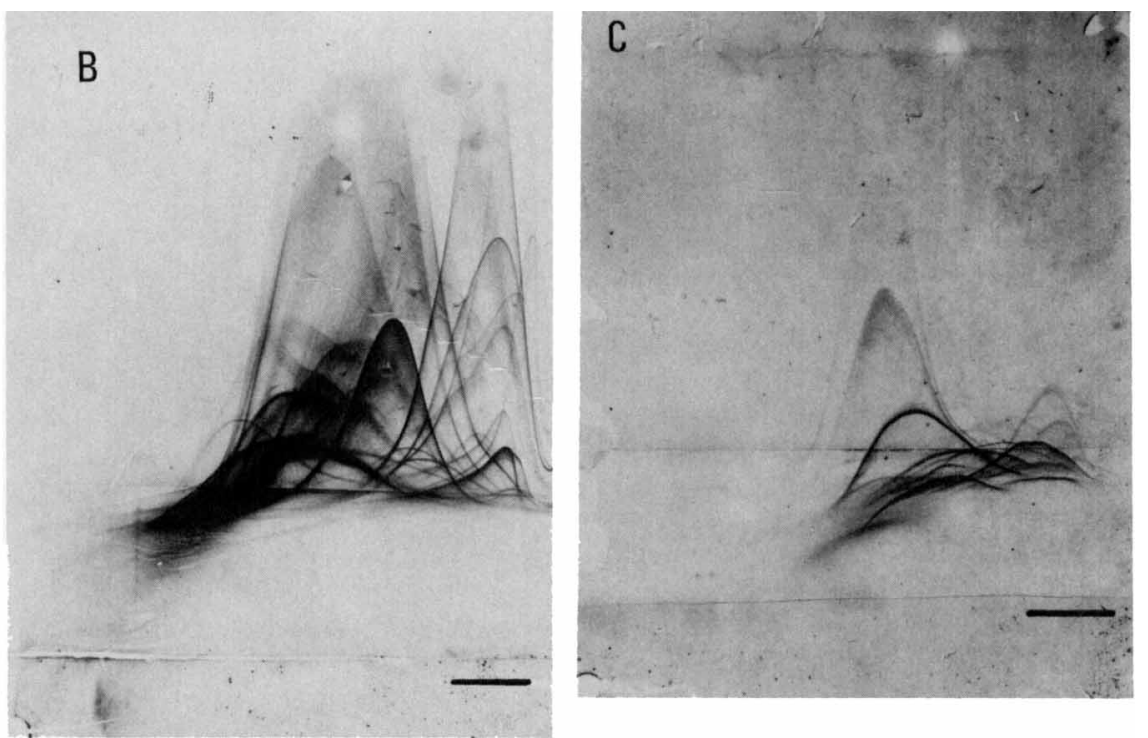

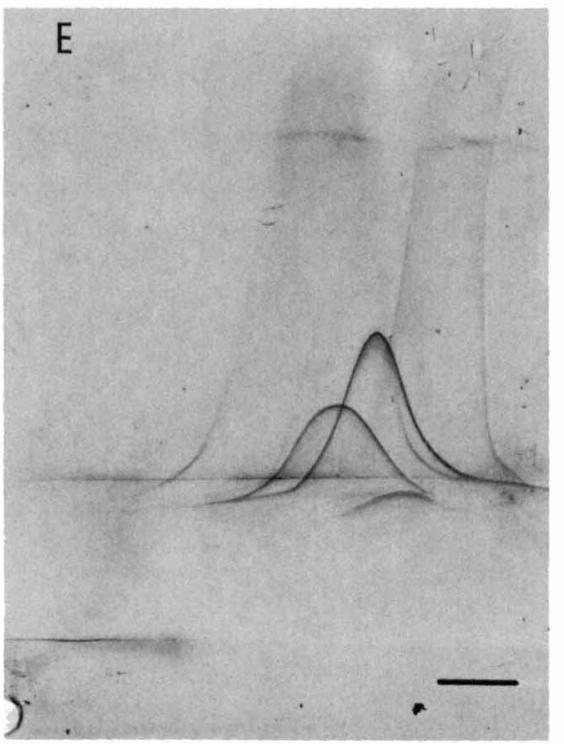

FIG. 4. Crossed immunoelectrophoresis in the heterologous system. The antibody used was $10 \mu$ of rabbit antiserum against $B$. distasonis ATCC $8503^{\mathrm{T}}$ extract per $\mathrm{cm}^{2}$. The antigens used were $10 \mu \mathrm{l}$ of $B$. thetaiotaomicron soluble extract (A), $10 \mu \mathrm{l}$ of $B$. ovatus soluble extract (B), $10 \mu \mathrm{l}$ of $B$. vulgatus soluble extract (C), $10 \mu \mathrm{l}$ of $B$. fragilis $\mathrm{NCTC} 9343^{\mathrm{T}}$ soluble extract (D), and $10 \mu \mathrm{l}$ of $B$. fragilis E323 soluble extract (E).

adenine dinucleotide phosphate, $17 \mathrm{mg}$ of glucose 6phosphate, $36 \mathrm{mg}$ of tetranitro blue tetrazolium, and $3 \mathrm{mg}$ of phenazine methosulfate.

\section{RESULTS}

The concentrations of soluble extracts ranged from 2 to 10 $\mathrm{g} /$ liter (Table 2). Anti-B. fragilis and anti-B. distasonis sera were obtained by pooling for each rabbit the serum samples that produced the most precipitates during line immunoelectrophoresis (8).

In the crossed-immunoelectrophoresis pattern developed with the $B$. fragilis system, 62 antigenic precipitates were detected. A number was attributed to each peak, starting from the anode side of the first-dimension electrophoresis gel (Fig. 1).

In the same way, 70 precipitates were identified with the B. distasonis system (Fig. 2).
Cross-immunoelectrophoresis with heterologous systems permitted us to study cross-reactions of the antigens with the two antisera (Fig. 3 and 4). For each system, the number of precipitates obtained was counted, and the percentage of common antigens was evaluated (Table 1).

Detection of enzymes. The presence of enzymes in the antigenic extracts was verified either by using API-ZYM strips (esterases and phosphatases) or by using zone electrophoresis (G6PDH and MDH).

The four enzymes were also found in the crossed immunoelectrophoresis performed with the $B$. fragilis system; $\alpha$-esterase corresponded to peak 53 of the reference pattern, phosphatase corresponded to peak $60, \mathrm{MDH}$ corresponded to peak 47, and G6PDH corresponded to peak 48 (Fig. 5).

With the $B$. distasonis system, $\alpha$-esterase corresponded to antigen 51 , phosphatase corresponded to antigen 58 , and $\mathrm{MDH}$ corresponded to antigens 30 and 35 ; none of the precipitates showed any G6PDH activity. 
Table 2 shows the enzyme activities obtained from crossed immunoelectrophoresis done with heterologous systems.

\section{DISCUSSION}

Crossed immunoelectrophoresis with the homologous system. Crossed immunoelectrophoresis performed with soluble extracts of $B$. fragilis $E 1^{\mathbf{T}}$ and $B$. distasonis and with their respective antisera demonstrated the antigenic complexity of these species, since 62 and 70 precipitation peaks, respectively, were demonstrated.

We emphasize the superiority of such a technique, which is already used for many microorganisms (notably for yeasts [8]) over such techniques as double immunodiffusion (Ouchterlony technique), in which only two or three precipitation arcs are revealed for an antigen of closely related preparations (1).

Thus, we obtained crossed-immunoelectrophoretic patterns that were reliable enough to serve as reference systems for the study of immunological communities of different Bacteroides species belonging to the $B$. fragilis group.

Crossed immunoelectrophoresis with the heterologous system. The reactions of antigens from different Bacteroides species with the two reference antisera showed speciesrelated differences.

In the $B$. fragilis system, the strain with the largest number of antigens in common with $B$. fragilis $\mathrm{E}^{\mathrm{T}}$ was $B$. fragilis $\mathrm{E} 2$, which is logical since these two strains belong to the same species. The species closest to $B$. fragilis was $B$. thetaiotaomicron; the species most distant was $B$. vulgatus (Table 1). The other species showed intermediate percentages of common antigens.

By using the method described above, no species appeared to be immunologically close to $B$. distasonis since the closest species, $B$. ovatus, did not show one-half the number of antigens of $\boldsymbol{B}$. distasonis (Table 1). However, the absence of cross-reactive antigens may have been due to the low concentration of the $B$. ovatus extract (11).

Therefore, our findings confirmed the validity of different species within the $B$. fragilis group, although we could not draw final conclusions as to the relative proximity of each

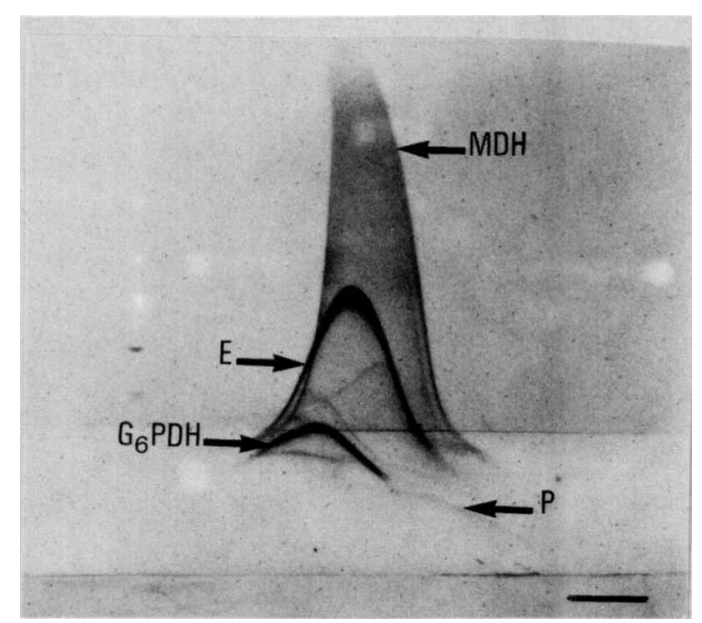

FIG. 5. Enzyme staining of a crossed-immunoelectrophoresis preparation. The antigen used was $10 \mu \mathrm{l}$ of $B$. fragilis NCTC $9343^{\mathrm{T}}$ extract. The antibody used was $10 \mu \mathrm{l}$ of the corresponding rabbit antiserum per $\mathrm{cm}^{2}$. P, Phosphatase; E, esterase.
TABLE 3. Specific identification of Bacteroides strains belonging to the $B$. fragilis group with antigenic enzyme patterns determined by crossed immunoelectrophoresis

\begin{tabular}{|c|c|c|c|c|c|}
\hline \multirow{2}{*}{ Antigen } & \multicolumn{3}{|c|}{$\begin{array}{l}\text { B. fragilis } \\
\text { antiserum }\end{array}$} & \multicolumn{2}{|c|}{$\begin{array}{l}\text { B. distasonis } \\
\text { antiserum }\end{array}$} \\
\hline & MDH & $\mathrm{G} 6 \mathrm{PDH}$ & Phosphatase & Esterase & Phosphatase \\
\hline B. fragilis $\mathrm{E} 1^{\mathrm{T}}$ or $\mathrm{E} 2$ & + & + & + & - & - \\
\hline B. thetaiotaomicron & + & + & - & - & - \\
\hline B. ovatus & + & + & - & - & + \\
\hline B. vulgatus & + & - & - & - & + \\
\hline B. distasonis & + & - & - & + & + \\
\hline
\end{tabular}

species to the others. Therefore, it will be necessary to use antisera obtained from these other species and to study several strains of each species.

Enzyme activity revelations on antigenic precipitates. Our method enabled us to identify some antigens of the two reference patterns to enzymes. The value of this finding is twofold; (i) the identification of group- or species-specific antigens is facilitated, as it is based on a small number of antigens that are easily identifiable, compared with the complexity of the patterns observed after staining with Coomassie blue, and (ii) there is taxonomic value since antigenic communities of enzymes are studied between species.

The phosphatase of $B$. fragilis seems to be species specific; it is identical for the two subspecies of $B$. fragilis (strains $E 1^{\mathrm{T}}$ and $\mathrm{E} 2$ ) and does not share antigens with any other species when it is tested by crossed immunoelectrophoresis. This also applies to the esterases of $B$. fragilis and $B$. distasonis, but the results are more difficult to analyze since certain precipitates occur nonspecifically (2).

The MDH is common to, and shared by, every system; therefore, it is an antigen which is common to all members of the $B$. fragilis group.

The alkaline phosphatase of $B$. distasonis is identical to the alkaline phosphatases of $B$. ovatus and $B$. vulgatus. However, the latter two species can be distinguished by their G6PDHs; that of $B$. ovatus is actually identical to the G6PDH of $\boldsymbol{B}$. fragilis $\mathrm{E1}^{\mathrm{T}}$, just like the G6PDH of $\boldsymbol{B}$. fragilis $\mathrm{E} 2$ and the G6PDH of $B$. thetaiotaomicron.

The G6PDH of $B$. distasonis differs from that of $B$. fragilis, but the absence of the corresponding antibody in anti- $B$. distasonis antiserum prevented us from determining community between the G6PDHs of $B$. distasonis and $B$. vulgatus. Therefore, the availability of an anti- $B$. vulgatus antiserum would be of interest. The method described above enabled us to differentiate most species of the $B$. fragilis group through their enzyme activities; such a demonstration is not possible, however, if one is solely concerned with the presence or absence of an enzyme (9).

Our results are summarized in Table 3. No two of the species have identical profiles. Table 2 shows that with two different antisera and four enzyme activities it is possible to differentiate the five species of the $B$. fragilis group which we studied.

Our results obtained by using Coomassie blue staining are also interesting; the two strains of $B$. fragilis studied are closely related (no difference in antigenic enzymes), and $B$. thetaiotaomicron appears to be the species that is most similar to $B$. fragilis.

Contrary to the results obtained with Coomassie bluestained crossed-immunoelectrophoresis preparations, the enzymatic staining of precipitates permitted differentiation 
of $B$. ovatus from $B$. vulgatus, which supports the notion of different species within the $B$. fragilis group.

\section{LITERATURE CITED}

1. Beerens, H., P. Wattre, T. Shinjo, and C. Romond. 1971. Premiers résultats d'un essai de classification sérologique de 131 souches de Bacteroides du groupe fragilis. Ann. Inst. Pasteur Paris 121:187-198.

2. Brogren, C. H., and T. C. Bog-Hansen. 1973. Enzyme characterization in quantitative immunoelectrophoresis. An enzymological study of human serum esterases, p. 37-51. In N. H. Axelsen et al. (ed.), Quantitative immunoelectrophoresis. Blackwell Scientific Publications, Oslo.

3. Cato, E. P., and S. L. Johnson. 1976. Reinstatement of species rank for Bacteroides fragilis, Bacteroides ovatus, Bacteroides distasonis, Bacteroides thetaiotaomicron, and Bacteroides vulgatus: designation of neotype strains for Bacteroides fragilis (Veillon and Zuber) Castellani and Chalmers and Bacteroides thetaiotaomicron (Distaso) Castellani and Zuber. Int. J. Syst. Bacteriol. 26:230-237.

4. Cousland, G., and I. R. Poxton. 1983. Analysis of lipopolysaccharide of Bacteroides fragilis by sodium dodecyl sulfate polyacrylamide gel electrophoresis and electroblot transfer. FEMS Microbiol. Lett. 20:461-465.

5. Cousland, G., and I. R. Poxton. 1984. Crossed immunoelectrophoresis and ELISA of the cell surface antigens of Bacteroides fragilis. J. Gen. Microbiol. 130:645-665.

6. Finegold, S. M. 1977. Anaerobic bacteria in human disease. Academic Press, Inc., New York.

7. Gabriel-Bruneau, S. M., and R. M. F. Guinet. 1984. Antigenic relationships among some Candida species studied by crossedline immunoelectrophoresis: taxonomic significance. Int. J. Syst. Bacteriol. 34:227-236.

8. Guinet, R. M. F., and S. M. Gabriel. 1980. Candida albicans group A-specific soluble antigens by quantitative immunoelectrophoresis. Infect. Immun. 29:853-858.

9. Hofstad, T. 1980. Evaluation of the API ZYM system for identification of Bacteroides and Fusobacterium species. Med. Microbiol. Immunol. 168:173-177.

10. Hofstad, T. 1982. Immunochemical studies of partially degraded LPS from Bacteroides fragilis IPL E 323. Acta. Pathol. Microbiol. Immunol. Scand. Sect. B 90:281-287.

11. Hoiby, N. 1975. Cross-reactions between Pseudomonas aeruginosa and thirty-six other bacterial species, p. 187-196. In N. H. Axelsen (ed.), Quantitative immunoelectrophoresis. New developments and applications. Universitätforlaget, Oslo.

12. Holdeman, L. V., R. W. Kelley, and W. E. C. Moore. 1984. Genus 1. Bacteroides Castellani and Chalmers 1919, 959 $9^{\mathrm{AL}}$. p. 604-631. In N. R. Krieg and J. G. Holt (ed.), Bergey's manual of systematic bacteriology, vol. 1. The Williams \& Wilkins Co., Baltimore.

13. Kasper, D. L., M. E. Hayes, B. G. Reinap, F. O. Craft, A. B.
Onderdonk, and B. F. Polk. 1977. Isolation and identification of encapsulated strains of Bacteroides fragilis. J. Infect. Dis. 136: $75-81$.

14. Kasper, D. L., and M. W. Seiler. 1975. Immunochemical characterization of the outer membrane complex of Bacteroides fragilis subspecies fragilis. J. Infect. Dis. 132:440-450.

15. Lambe, D. W., Jr., and D. A. Moroz. 1976. Serogrouping of Bacteroides fragilis subspecies fragilis by the agglutination test. J. Clin. Microbiol. 3:586-592.

16. Lowry, O. H., N. J. Rosebrough, A. L. Farr, and R. J. Randall. 1951. Protein measurement with the Folin phenol reagent. J. Biol. Chem. 193:265-275.

17. Moore, W. E. C., and L. V. Holdeman. 1973. New names and combinations in the genera Bacteroides Castellani and Chalmers, Fusobacterium Knorr, Eubacterium Prévôt, Propionibacterium Delwich, and Lactobacillus Orla-Jensen. Int. J. Syst. Bacteriol. 23:69-74.

18. Moore, W. E. C., and L. V. Holdeman. 1974. Human fecal flora: the normal flora of 20 Japanese-Hawaiians. Appl. Microbiol. 27:961-979.

19. Onderdonk, A. B., D. L. Kasper, R. L. Cisneros, and J. G. Bartlett. 1977. The capsular polysaccharide of Bacteroides fragilis as a virulence factor: comparison of the pathogenic potential of encapsulated and unencapsulated strains. J. Infect. Dis. 136:82-89.

20. Owen, P., and M. R. J. Salton. 1975. Antigenic and enzymatic architecture of Micrococcus lysodeikticus membranes established by crossed immunoelectrophoresis. Proc. Natl. Acad. Sci. U.S.A. 72:160-171.

21. Poxton, I., and R. Brown. 1979. Sodium dodecyl sulfatepolyacrylamide gel electrophoresis of cell-surface proteins as an aid to the identification of the Bacteroides fragilis group. J. Gen. Microbiol. 112:211-217.

22. Sedallian, A., and C. Romond. 1982. p. 494-508. In L. Le Minor and $\mathrm{M}$. Véron (ed.), Bactériologie médicale. Flammarion, Paris.

23. Shah, H. N., and M. D. Collins. 1983. A review. Genus Bacteroides: a chemotaxonomical perspective. J. Appl. Bacteriol. 55:403-416.

24. Shah, H. N., and R. A. D. Williams. 1982. Dehydrogenase pattern in the taxonomy of Bacteroides. J. Gen. Microbiol. 128:2955-2965.

25. Weeke, B. 1973. General remarks on principles, equipment, reagents and procedures, p. 15-35. In N. H. Axelsen, J. Kroll, and B. Weeke (ed.), A manual of quantitative immunoelectrophoresis. Methods and applications. Blackwell Scientific Publications, Oslo.

26. West, S. E. H., and T. D. Wilkins. 1980. Vaspar broth-disk procedure for antibiotic susceptibility testing of anaerobic bacteria. Antimicrob. Agents Chemother. 17:288-291.

27. Wren, M. W. D., A. W. F. Baldwin, C. P. Eldon, and P. J. Sanderson. 1977. The anaerobic culture of clinical specimens: a 14 month study. J. Med. Microbiol. 10:49-61. 